\title{
METHODOLOGICAL PROPOSAL ABOUT THE ROLE OF LANDSCAPE IN THE TOURISM DEVELOPMENT PROCESS IN RURAL AREAS: THE CASE OF MOLISE REGION (ITALY)
}

Luigi Mastronardi, Vincenzo Giaccioํㅜ, Agostino Giannelli, Angela Stanisci²

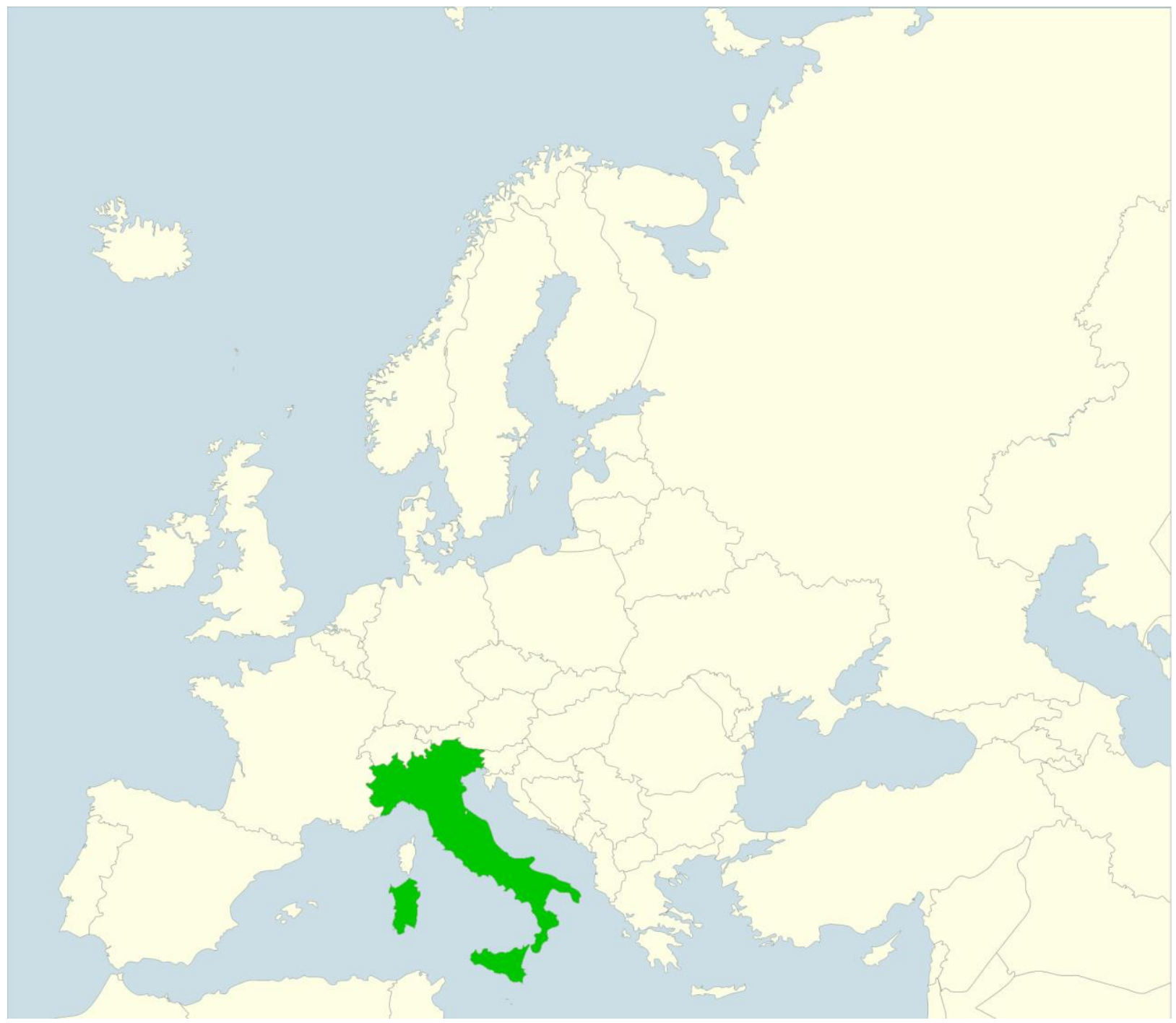

${ }^{1}$ Prof. Luigi Mastronardi, Prof. Vincenzo Giaccio, Department of Economics, University of Molise, Via De Sanctis, 86100 Campobasso, Italy; luigi.mastronardi@unimol.it, giaccio@unimol.it

2 Dott. Agostino Giannelli, Prof. Angela Stanisci, Department of Biosciences and Territory, University of Molise, Contrada Fonte Lappone 8, 86090 Pesche (IS), Italy; agostino.giannelli@unimol.it, stanisci@unimol.it 


\begin{abstract}
The landscape has always been a fundamental factor in defining tourist flow attraction for local development. In this paper, landscape related to tourism have been analysed using three different measurements through appropriate performance indicators and rationalised with the aim of identifying a scheme of mutual relations. Applying advanced statistical methods of ranking and data synthesis, the area investigated (Molise, Italy) has been divided into different zones. Each area described has a specific relation between tourism and landscape useful in the implementation of optimal promotion strategies and valorisation of the area. In marginal areas, tourism can have an excellent growth potential, since they are characterized by the high quality of the landscape. However, the analysis highlights some gap areas, which means the existence of areas with high quality of the natural and agricultural landscape is not associated with an appropriate tourism development, or areas where the high tourism development is not associated with an appreciable quality of the landscape.
\end{abstract}

Keywords: Landscape, biodiversity, agriculture, tourism, rural areas, ecosystem services, Italy.

Abstract: II paesaggio è sempre stato un fattore imprescindibile nel determinare la capacità di attrarre flussi turistici per lo sviluppo locale. In questo lavoro turismo, paesaggio naturale e agrario sono stati analizzati mediante opportuni indicatori e messi a sistema con lo scopo di delinearne lo schema di relazioni reciproche. Applicando metodi statistici di classificazione e sintesi dei dati, l'area oggetto di studio (Molise, Italy) è stata di conseguenza divisa in zone, ognuna delle quali descrive uno specifico rapporto tra turismo e paesaggio utile nell'implementazione delle strategie di promozione e valorizzazione del territorio. Nelle aree marginali, il turismo può avere grandi potenzialità di sviluppo, poiché sono caratterizzate da un'alta qualità del paesaggio. Tuttavia, le analisi evidenziano la presenza di alcune aree gap, ovvero zone dove l'alta qualità del paesaggio naturale e agrario non si associa ad un adeguato sviluppo turistico, oppure aree dove l'elevato sviluppo turistico non è associato ad una qualità apprezzabile del paesaggio.

Keywords: Paesaggio, biodiversità, agricoltura, turismo, aree rurali, servizi ecosistemici Italia

\title{
1. Introduction
}

The European rural areas have been undergoing a rather intensive transformation process regarding the social, economic and environmental sphere (OECD, 2006a; Brunori, 2010). These dynamics have been defined by the process of economic development, which has led to a substantial change of the economic and social role of agriculture (European Commission, 1988). Yet, on the other hand, a new relationship between urban and rural areas has been developed (Dwyer et al., 2003). This linkage is directly observable in reference to both the "spatial distribution" of productive activities and the "functional distribution" that different areas carry out in the economic system (Basile \& Cecchi, 2001).

To summarise, the socio-spatial guidelines that have sensibly changed the rural areas are:

i) the weakening of the ability of rural areas to produce the so-called "ecosystem services";

ii) the ageing of the rural population;

iii) the territorial dispersion of industrialization;

iv) the contro-urbanisation;

v) consumption models changes.

Since the 1990s, rural areas have been interested in a new rebuilding process (Marsden, 1998) where agriculture, considered as an activity oriented solely towards goods production (Murdoch 
\& Ward, 1997), has acquired a multifunctional role, considering the sector's ability to jointly produce commodities and non-market outputs (Murdoch et al., 2003).

Rural areas are able to offer local resources in a sustainable and conservative productive process from which an emerging "return to farm life movement" is being created as an answer to globalization ${ }^{3}$, which has deleted every form of territorial strength and productive diversity (van der Ploeg, 2009).

As a result, tourism has a central role in revitalizing rural areas (Briedenhann \& Wickens, 2004; Cavallo \& Marino, 2014), above all in those areas where a high quality tourism request is strictly associated with natural, cultural and gastronomic resources (Giaccio \& Mastronardi, 2011; Ohe \& Ciani, 2011; Mastronardi et al., 2015, a, b).

The spread of rural tourism is based on culture economy (Ray, 1998), on new consumption models and on the utilization of the countryside (Kneafsey, 2001; Ray, 2003). Conceptually, rural tourism does not have a univocal meaning (Roberts \& Hall, 2001; Fleischer \& Tchetchik, 2005) and it includes all forms of tourism related to the countryside (Sharpley, 1996), namely: agritourism, farm tourism, rural tourism, green tourism, eco-tourism, soft tourism, alternative tourism, etc.

These labels are often used interchangeably with "agritourism" (Potočnik-Slavič \& Schmitz, 2013) because most countries do not have a specific legislation for each kind of tourism in the countryside.

Nevertheless, rural tourism is considered as a destination of community ${ }^{4}$ type (Franch, 2010) and, considering this point, it is a complex phenomenon and highly differentiated (Frochot, 2005). Its effects depend on the single territory's characteristics and on the mode with which private and public sectors configure in the relations between the tourism product and local resources. Rural tourism is intrinsically territorial (Battaglini \& Mastronardi, 2015), as it is connected to the specific points that each destination can offer (Saxena et al., 2007), in terms of environmental diversity, architectural coherence, cultural and social wealth (Saxena \& Ilbery, 2008).

In rural tourism development, the countryside capital (Garrod et al., 2006) is a key factor (Cawley \& Gillmor, 2008; Forleo \& Mastronardi, 2008). Considering this point, the landscape component, as both primary and complementary asset (Gregori \& Piccinini, 2004) can have a key role in defining the attractiveness level of a rural locality, (Daugstad, 2008; Croce \& Perri, 2008; Mastronardi et al., 2012), above all in those areas lacking any other tourism interest, e.g. cultural assets. Ultimately, landscape can have an important role in identifying the satisfaction level of a tourism experience in the countryside (Sedlacek et al., 2009).

Landscape as an asset is a factor of reorganization and territorial competitiveness (Dematteis \& Governa, 2005; Daugstad et al., 2006). Its nature as "a public selective and local asset" (Cornes \& Sandler, 1996) allows it to be utilized and finalized for goods produced solely by the inhabitants of a specific area (Brunori \& Pieroni, 2006).

Summing up, landscape assets produce ecological, environmental, social, cultural andeconomic values (Turri, 2008; Printsmann et al., 2012; Cialdea \& Mastronardi, 2014a), through which it is possible to recognize and save an area's identity (Antrop, 2005; Cialdea \& Mastronardi, 2014b). In this manner, it represents the tool for project management of an integrated and sustainable model of territorial development (Marino \& Cavallo, 2009; Cialdea \& Mastronardi, 2016).

This article focuses on the relations between tourism and specific resources of rurality, which define the difference between rural tourism and another form of tourism (i.e. sea tourism) (Mastronardi \& Cipollina, 2009; Belletti \& Berti, 2011).

In this scenario, the aim of our research is to propose a new paradigmatic vision about factors that can stimulate tourism activities in rural areas. Particularly, we have been attempting to

\footnotetext{
3 In truth, this kind of trend became popular in the '60s' thanks to the awareness of detrimental effects on the environment of the indiscriminate use of pesticides ("Silent Spring", Rachel Carson, 1962) or after the first forms of tourism into the farms.

${ }^{4}$ Community type tourism refers to those areas that, acting as a single element, and through the interaction of local actors, are placed in the tourism market with a single brand (Franch, 2010).
} 
measure the relevance of the landscape, ceteris paribus other factors that could attract tourists in rural areas.

\section{Data and Methods}

The target area of our research is Molise - Central Italy (fig.1), characterized by a high level of rurality (Pistacchio, 2008; Cialdea \& Mastronardi, 2014c), with landscape and naturalistic elements of strong community interest (Carranza et al. 2006; Stanisci et al. 2008; Paura \& Stanisci, 2009). Moreover, this region shows a significant growth of activities strictly linked to tourism (Cialdea \& Mastronardi, 2014d).

Molise is the youngest Italian region, since it was established in 1963, when the region "Abruzzi e Molise" was split into two regions. With Aosta Valley Region, it is the smallest Italian Region, with important environmental, archaeological and architectural sites. It has a rather heterogeneous structure. Its landscape varies from a mostly mountainous (55\% of the surface) and hilly territory in the central area, while near the coast, its surface is characterized by plains and low hills. Due to this situation, there are strong setting differences regarding: the countryside, crop cultivation and soil use, spreading from the inner areas to the Adriatic coast (Di Marzio et al., 2008; Cialdea \& Mastronardi, 2014e).

Moreover, major landslides affect the whole Region; also, the Apennines divide Molise in remote mountains and a series of hills, making it difficult to get important road infrastructures and contributing to create a state of isolation.

Tourism accommodations, hotels in particular, are localized along the Adriatic coast, which attracts tourists from neighbouring regions, from northern Italy and in small part from foreign countries. The mountain areas, instead, are in the interest of other kinds of tourism settlements, such us B\&B, agritourisms and scattered hotels (a typical Italian tourism accommodation, called Albergo diffuso).

According to ISTAT (Italian National Institute of Statistics) in 2010, in Molise, there were 209,051 tourists for 680,141 days of stay; $90.4 \%$ came from Italy and $9.6 \%$ (15,692 tourists) were foreigners. Molise is the least visited region in Italy and it essentially records a seasonal tourism (summer tourism). With regards to the kind of accommodation, the $82.9 \%$ of tourists spend their stay in the hotels on the coast while, just a little percentage (17.1) prefer to stay in the mountains.

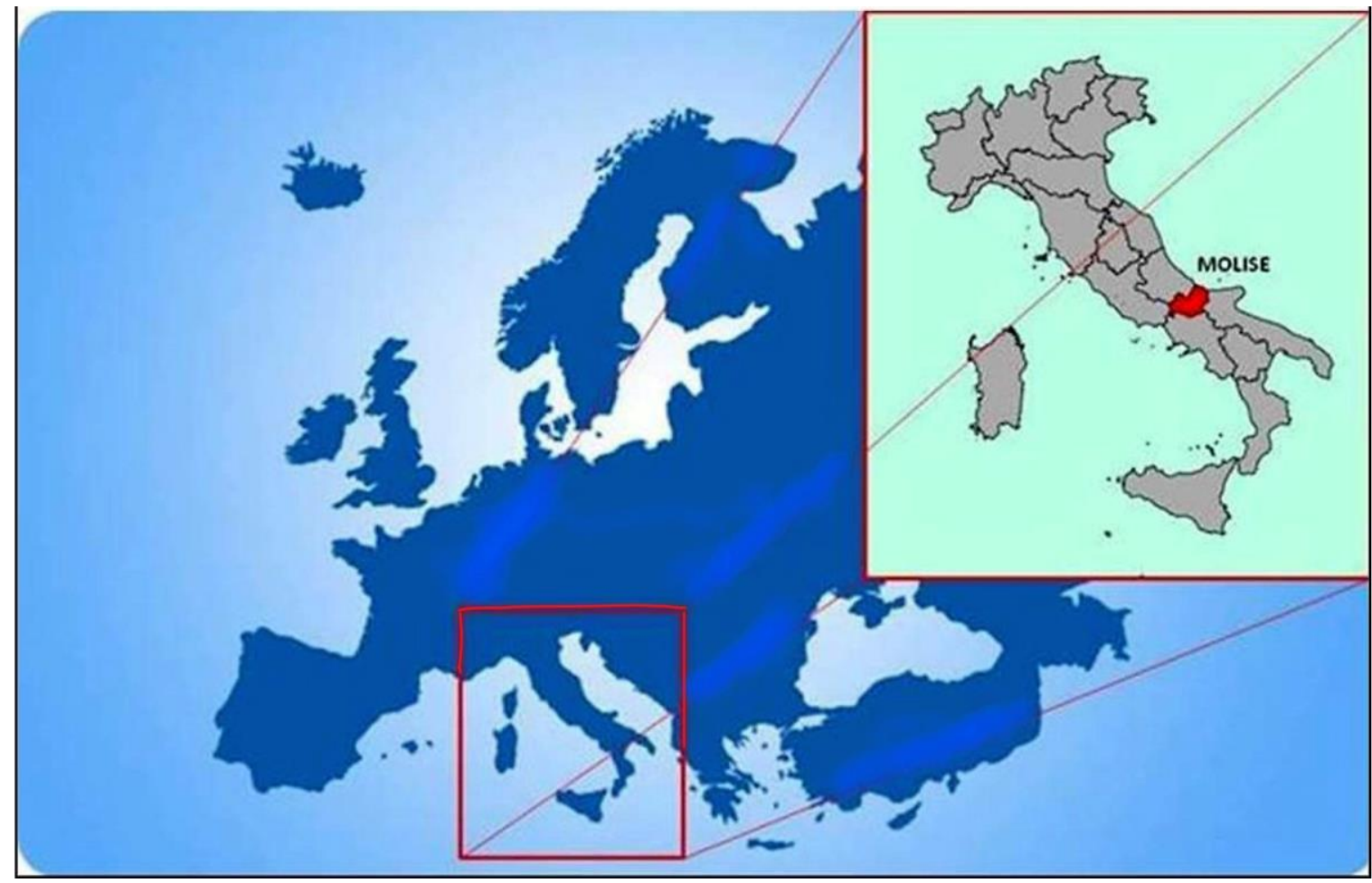

Fig 1. Local areas investigated. Source: own processing, 2016 
The analysis focused on the natural and agricultural landscape features and the level of tourism development at the municipal scale.

To analyze the territory of each municipality in Molise, we chose indicator groups related to tourism development and the characteristics of the natural and agricultural landscape that allowed for the identification of the relationship between the landscape mosaic and tourism offer (OECD, 2006b; Mastronardi et al. 2015c).

This landscape analysis covers both natural and agricultural elements with the main aim of highlighting the specific territorial features of the local area studied, and defining the role of the landscape as a discriminating variable for tourism development.

To describe the natural landscape characteristics, specific indicators were selected (table 1) which allowed us to better explain the significant aspects referred to nature as a direct function of the biodiversity level (considering flora and wildlife) and as an inversion function of human activity and intense use of natural resources. These indicators are partially utilized in other research studies with different targets.

Tab 1. Indicators of the natural landscape.

\begin{tabular}{|c|c|}
\hline DENOMINATION & DEFINITION \\
\hline Coverage of natural areas & $\%$ areas CLC (2006) belonging to $3 x x-5 x x$ class \\
\hline Coverage SCI Areas and SACs & $\%$ areas included in Nature Network 2000 \\
\hline Coverage of humid areas & $\begin{array}{l}\% \text { areas occupied by lake basins, rivers and riparian vegetation } \\
\text { in a buffer of } 50-100 \mathrm{M} \text { along the main and } 20 \mathrm{M} \text { secondary } \\
\text { waterways. }\end{array}$ \\
\hline $\begin{array}{l}\text { Coverage of primary habitats in } \\
\text { SCl areas }\end{array}$ & $\begin{array}{l}\% \text { areas interested in the habitat according to law (n. 43/92 } \\
\text { CEE) priority }\left({ }^{*}\right) \text { in the Sites of Community Interests (SCI) }\end{array}$ \\
\hline $\begin{array}{l}\text { Availability of suitable areas for } \\
\text { wildlife threatened in SCl areas }\end{array}$ & $\begin{array}{l}\% \text { suitable area (classes } 2 \text { and } 3 \text { of the National Ecological } \\
\text { Network) for the vertebrate reproductive wildlife with a higher } \\
\text { interest of conservation }\end{array}$ \\
\hline $\begin{array}{l}\text { Availability of core areas for the } \\
\text { conservation }\end{array}$ & $\begin{array}{l}\text { Specific homogeneous naturalistic areas (CLC level III) / } \\
\text { municipality areas }\end{array}$ \\
\hline Altitude Range & $\begin{array}{l}\text { Range of different potential referred to altitude gradient } \\
(Q=\text { altitude oat sea level.): }[Q-Q \min ] /[Q \max -Q \min ]\end{array}$ \\
\hline Diversity & $\begin{array}{l}\text { Measure of the heterogeneous level (evenness) of the groups } \\
3-5 \text { at III level Corine }[0=\min , 1=\max ]\end{array}$ \\
\hline
\end{tabular}

In regards to the naturalistic aspects, the data used for this research are from thematic cartographic documents and managed in the GIS system: computerized land coverage maps ${ }^{5}$, Nature 2000 map network of the Molise region and community interest habitat maps ${ }^{6}$.

In analyzing the agricultural landscape, we can define its uniqueness, as "the tracks that Man, with his farming activity and upon its completion consciously and systematically imprints upon the natural landscape" (Sereni, 1961).

\footnotetext{
${ }^{5}$ http://www.pcn.minambiente.it/PCN/

${ }^{6}$ http://cartografia.regione.molise.it/mapserver.html
} 
Specifically, the main purpose of this research paper is to identify:

a) agricultural areas of High Natural Value Farmlands (HNVF) (EEA, 2004), recognized as those areas where "agriculture represents the use of the principal terrain (generally considered as prevalent). Thus, maintaining and associating it with a high number of different species or habitats, and/or particular species of community interest ${ }^{\prime \prime}$ (Beaufoy et al., 1994; Bignal \& McCracken, 1996);

b) the elements of historical and traditional interest which characterize an agricultural landscape, defined as those elements considered typical in a specific area, over a long period of time ( or over many centuries) and which have evolved and slowly become traditionalized with the passing of time.

Tab 2. Indicators of the agricultural landscape.

\begin{tabular}{|c|c|}
\hline DENOMINATION & DEFINITION \\
\hline $\begin{array}{l}\text { Level of agricultural use of the } \\
\text { land }\end{array}$ & Net Agricultural Area (NAA) local surface \\
\hline Intensity of agricultural uses & Utilized Agricultural Area (UAA) / NAA \\
\hline $\begin{array}{l}\text { Agricultural Areas of High } \\
\text { Natural Value (AAHNV) }\end{array}$ & $\begin{array}{l}\text { \% IPA (Important Plant Areas) and IBA (Important Bird Areas) in } \\
\text { the CLC (2006) 2xx Group }\end{array}$ \\
\hline $\begin{array}{l}\text { Impact of the extensive } \\
\text { agricultural uses }\end{array}$ & $\begin{array}{l}\text { i) } 1 \text { - [intensive cultivation surface (2111) + irrigated (212)] / } \\
\text { surface class CLC } 2 x x x \\
\text { ii) NAA biological / NAA total (\%) }\end{array}$ \\
\hline Diversity & $\begin{array}{l}\text { Level of heterogeneity }{ }^{8} \text { (evenness) of group } 2 \text { at the III level } \\
\text { Corine }[0=\min , 1=\max ]\end{array}$ \\
\hline $\begin{array}{l}\text { Agro-cultural elements of } \\
\text { historical interest }\end{array}$ & $\%$ "sheep track" (Tratturi) protected surface areas ${ }^{9}$ \\
\hline Buildings & $\begin{array}{l}\text { Value of the historic-rural heritage on a local scale, measured } \\
\text { through an ad hoc index, which considered different typologies } \\
\text { registered in relation to the local surface territory. Each type has } \\
\text { been measured through a comparative scale based on three } \\
\text { levels of architectural interest and conservation. }\end{array}$ \\
\hline
\end{tabular}

Referring to this point, the agricultural landscape is analyzed based on the following points: a) level of agricultural use of the land; b) intensification of agricultural activity; c) presence of natural elements; d) level of diversity/heterogeneity cultivation; e) existence of agro-cultural elements of historical and archeological interest. The indicators utilized are listed in table 2.

\footnotetext{
7 The European Environmental Agency (2004) defines three different types of areas: Type 1 includes areas with a high proportion of semi-natural vegetation (e.g. natural meadows). Type 2 are those areas with a presence of an agricultural mosaic of low intensity agriculture and natural elements, semi-natural and structural (e.g. hedges, stonewalls, rows, short waterways, etc.). Type 3 includes agricultural areas which sustain rare species or with a high level of global, European, national and/or local wealth.

8 This ratio has been corrected taking into consideration different agricultural typologies (CLC 242 e 243) as characterized by their internal heterogeneity due to the combination of various typologies, with three dominant ones. In the light of this, we propose the following formula: Even(c) $=$ [Even +3 * (\%Cop CLC 24x)]/Even max.

9 The "tratturi" are grassy walks/roadways used by shepherds/farmers and their flocks migrating down from the Apennine Mountains to the coast flat plains up the second half of the last century (Cialdea and Mastronardi, 2015; Mastronardi and Fanelli, 2008). Nowadays, they are object of safeguard projects aimed at conserving and enhancing rural areas and their historical patrimony. In this paper, we have proposed them as instruments for the construction of a conservation index of a traditional rural landscape.
} 
With regards to the agricultural aspects, we have utilized ISTAT data (2010) referring to Net Agricultural Area (NAA) and Utilized Agricultural Area (UAA).

To describe the level of tourism development, specific indicators were selected (table 3). ISTAT is the Data source we used for our analysis. It is the only producer of an official statistics in Italy at Municipal level.

We chose the following indicators, as they are considered the most useful for the purposes of the research. Briefly, the first, second and third indicators are used by ISTAT to define the tourism development level of a place (Municipality) ${ }^{10}$. About "Infrastructures availability", the choice is due to the peculiarity of the Molise. Here, there are not a lot of important road infrastructures. Moreover, landslides affect a large percentage of the territory. So the proximity of a tourism area to such major roads, it is considered in a positive way (Molise Region, 2010).

Tab 3. Tourism Development Indicators.

\begin{tabular}{|c|c|}
\hline DENOMINATION & DEFINITION \\
\hline $\begin{array}{l}\text { Total tourism accommodation } \\
\text { establishments }\end{array}$ & Number of beds for each Municipality \\
\hline $\begin{array}{l}\text { Other collective } \\
\text { accommodation } \\
\text { establishments }\end{array}$ & $\begin{array}{l}\text { Number of beds in non-hotel accommodation (tourist camp-sites, } \\
\text { holiday villages, tourist camp-sites and holiday villages-mixed } \\
\text { forms, holiday dwellings (rented), farmhouses, youth hostels, } \\
\text { holidays homes, mountain refuges, bed and breakfast, other } \\
\text { accommodation n.e.c.) }\end{array}$ \\
\hline $\begin{array}{l}\text { Average size of } \\
\text { accommodation structures }\end{array}$ & Average number of beds for each structure \\
\hline Infrastructures availability & $\begin{array}{l}\text { Minimum distance from the main infrastructures (national } \\
\text { road/highways and railways) to downtown area }\end{array}$ \\
\hline
\end{tabular}

In the first step of our research, regarding all the different measurements investigated, we developed a cluster analysis on a hierarchical local level with the aim of regrouping common affinities considering similarities that emerged with indicators. During this phase, we also considered the Principal Component Analysis (PCA) (Hotelling, 1933; 1936) to point out via a biplot the relations between different groups of elements (single common) and variables utilized (indicators). The groups' relative direction towards the principle axis of the first principle plan (PCA1-2) allowed to identify a gradient for each dimension of the analysis. Thus, making it possible to set up a scale of the prevailing associations among the groups and the variables (ranging from very strong to very weak). For each dimension, we identified four different association levels, which defined different values of the natural and agricultural landscape, while at the same time, pinpointing different levels of tourism development. This classification was used to zone areas of regional territory taking into consideration natural landscape, agricultural landscape and tourism development level according to the chart in figure 2.

In the second step of our research, the level of association identified for each of the dimensions investigated has been recombined. The main aim was to identify areas of mutual accordance or discordance (fig. 3). Through the distribution of hierarchical levels in pairs on a hypothetical axis, following a top-down scheme, making it possible to identify different combinations that corresponded to regional territory areas (municipalities) with different relations models between natural landscape, agricultural landscape and tourism development. Therefore, it was possible to identify target areas (gap) where high-level values of the natural landscape and/or agricultural are

10 Averages are calculated by ISTAT as follows: Number of beds/Number of accommodation facilities (Tourism structures), for each Municipality. 
associated with a low presence of accommodation structures, which forecast potential tourism development of the territory. The concordance situations are represented by areas where it is possible to associate high (low) levels of the natural and agricultural landscape and high (low) values of tourism developments, and areas of pressure, characterized by a high presence of accommodation structures and low level of natural and agricultural landscape.

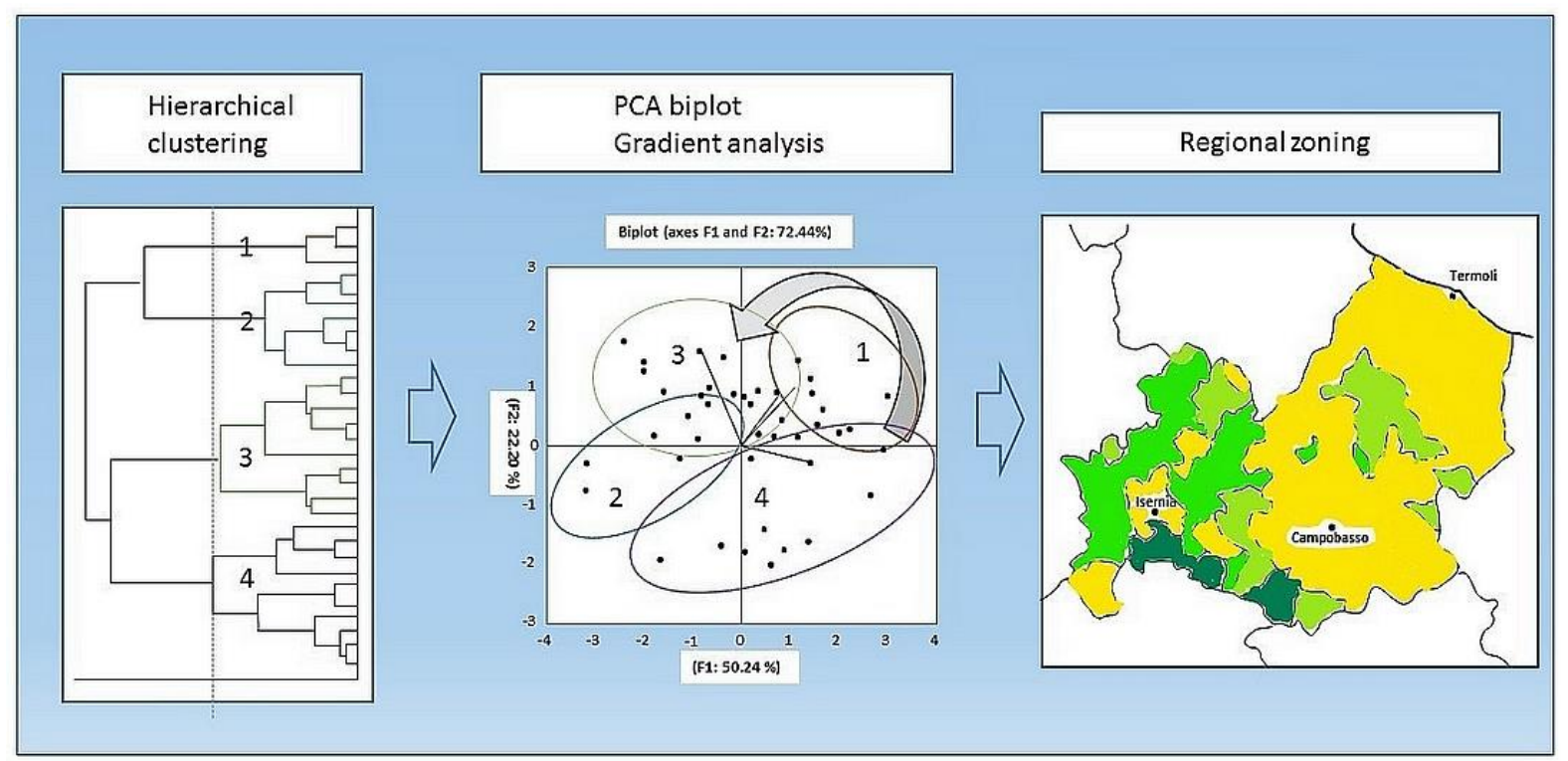

Fig 2. Methodological Scheme. Source: own processing, 2016
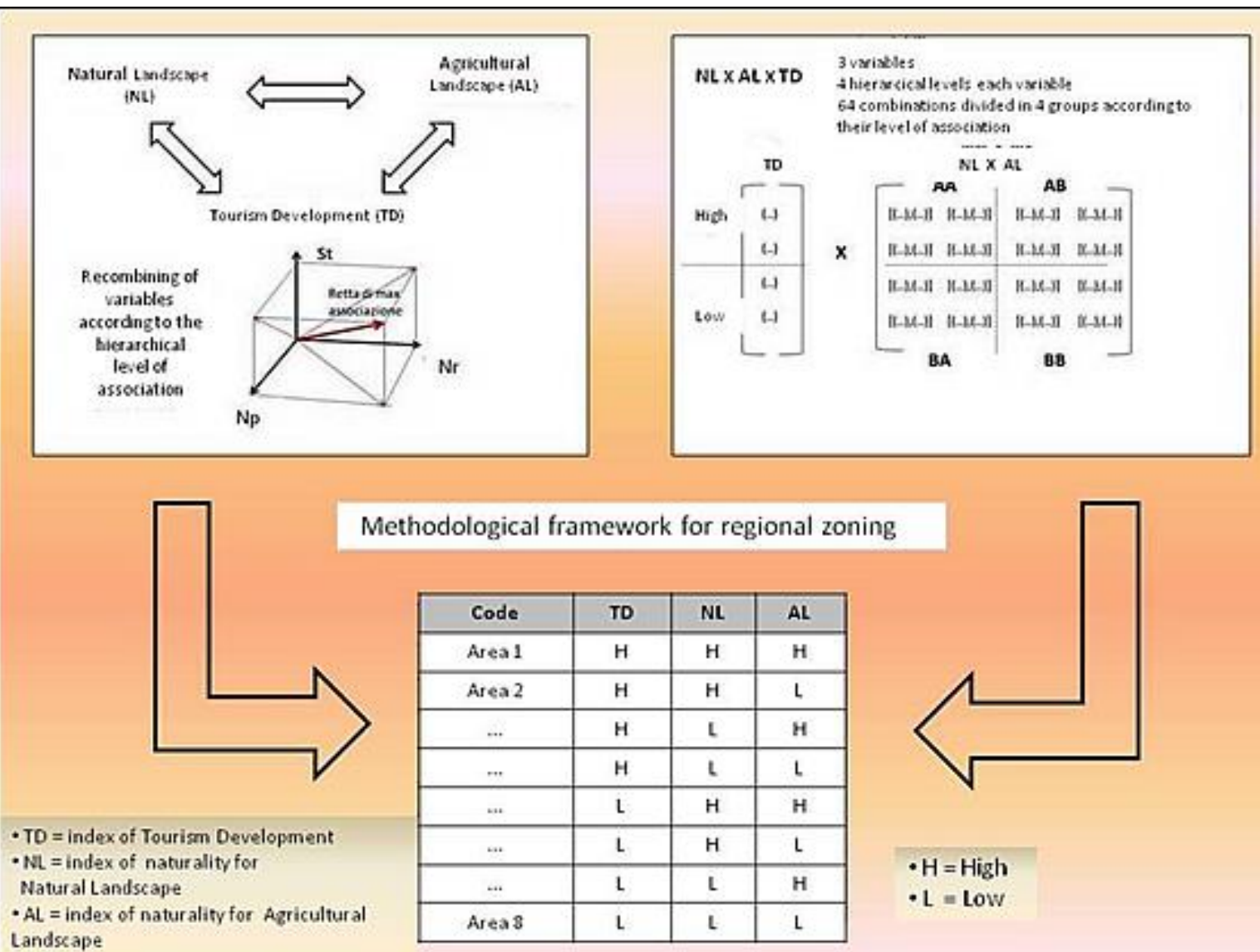

- $\mathrm{H}=$ High

$\cdot \mathrm{L}=\mathrm{Low}$

Fig 3. Methodology of Cross-Section Territory Zoning. Source: own processing, 2016 


\section{Results and discussion}

\subsection{Landscape and tourism features}

Figure 4 shows the characteristics of the natural landscape per zone, areas classified in one of four levels for the sake of simplicity:

a. Very high nature level: this area includes municipalities situated in the Matese Mountains in Molise, an area entirely encompassed in the largest regional $\mathrm{SCl}(25,000 \mathrm{ha})$ known as "La Gallinola- Monte Miletto-Monti del Matese" (IT7222287). A low level of human presence and a high level of natural integrity, sustained by the wealth and extension of community interest habitat, characterize this area. Large beech forests, rupestrian environments and high-altitude pastures mostly characterize it. This territory also comprises of considerable areas suitable for protected wildlife survival, in particular, wolves and many birds of prey.

b. High nature level: these areas are principally found in the province of Isernia (Alto Molise, PNALM), identified as those territories with particular orographic conditions which have discouraged human settlement. These conditions, however, have favored the growth of oak, beech and fir tree forests which have provided suitable habitats housing highly protected wildlife species (for example the Marsican bear). The naturalistic importance of these areas derives from the fact that they are close to or actually part of large natural parks (National Park of Abruzzo, Latium and Molise and the National Park of the Majella) acting as ecological corridors for the Southern Apennines, thus connecting the Samnium Mountains and Irpinia (Campania).

c. Medium nature level: includes the surface within the $\mathrm{SCl}$ area identified as "Guardialfiera Lake-Monte Peloso" (2.850 ha). This zone contains a significant humid area for the protection of winged- wildlife, recognized as SACs. Other areas of this level are situated close to Occhito Lake (SCI IT7222248), in some municipalities of the Matese area (Sepino and Boiano), in the SCI area of "Montagnola Molisana" (IT212135) and the municipality of Agnone, where the SCI area IT218215 known as "Abeti Soprani-Monte Campo-Monte Castel Barone-Sorgenti del Verde" is located.

d. Low nature level: includes hills and flatlands where the dominant elements are cultivated fields upon significant extensions of land (central and costal area of Molise).

With regards to Figure 4, describing the different features of the natural landscape, the figure 5 highlights the features of the agricultural landscape. It shows a lower degree of variation between the extremes of the classes (from a low to a very high level in the first case, from a low to a medium-high level in the second case with a prevalence of intermediate values) and a greater heterogeneity in the composition of the landscape (in the first case the province of Campobasso on the eastern side has low and relatively uniform values, while in the second case the landscape shows a more diversified pattern):

a. Agricultural landscape of mid-high level: in the light of landscape and agriculture, the most noteworthy places are characterized by a relatively greater importance of agricultural areas with natural spaces and forests that form an articulated mosaic scattered with human settlements. In these range mountain areas in Isernia province are found (northern part of Molise, with the exception of municipalities closely situated to the Sangro River Valley where the forest component is dominant) and the towns of the Samnium Area (the Fortore River Valley and the northern part of the Biferno Valley).

b. Agricultural landscape of middle-low level: typical of the Trigno River Valley (near the Abruzzo Region borders) and of the northern Molise coast, due to a less intensive use of the agricultural soil. The Venafro plain area, which hosts a recently constructed historicrural national park dedicated to the millennial olive cultivation, has a very low value level of agricultural landscape due to the high ratio of the human presence and the low acreage of the agricultural soil. The historic importance associated with the itinerant pastoralism roadways ("tratturi") and rural architecture is highly widespread. However, its influence is 
relatively low owing to the deterioration and the abandonment of the roadway and of the still recognizable structures.

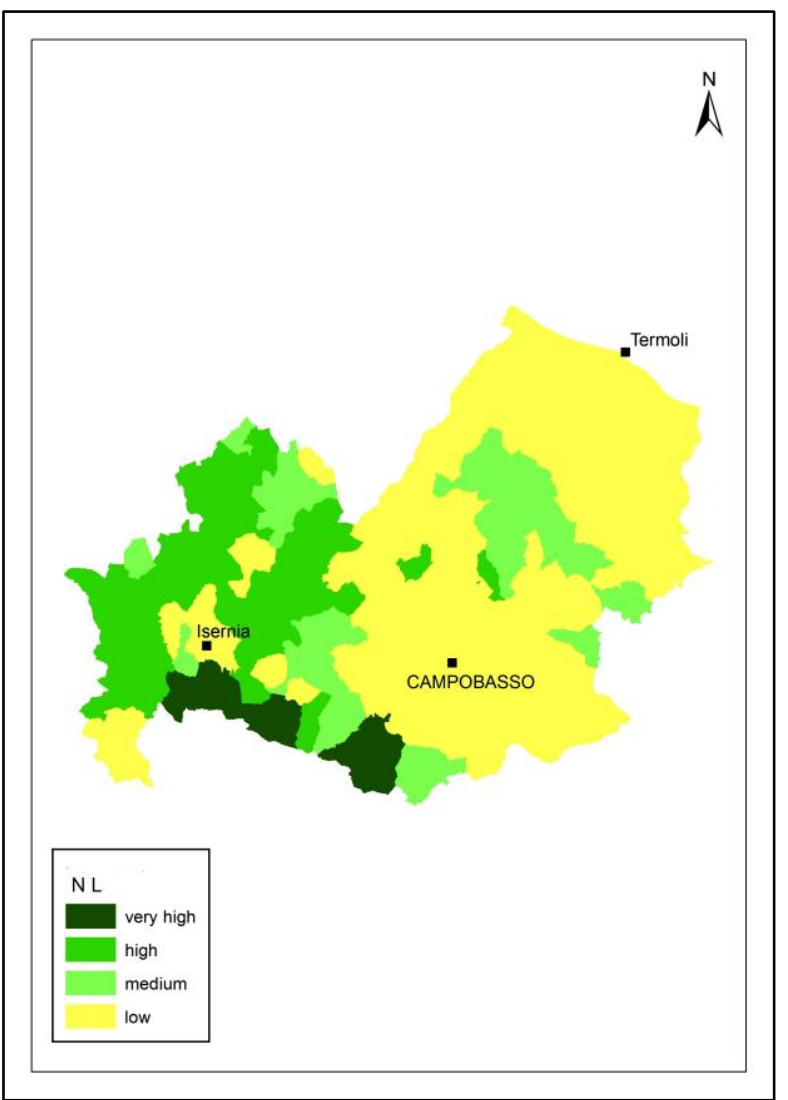

Fig 4. Zoning considering landscape and naturalistic indicators of the Molise region. Source: own processing, 2016

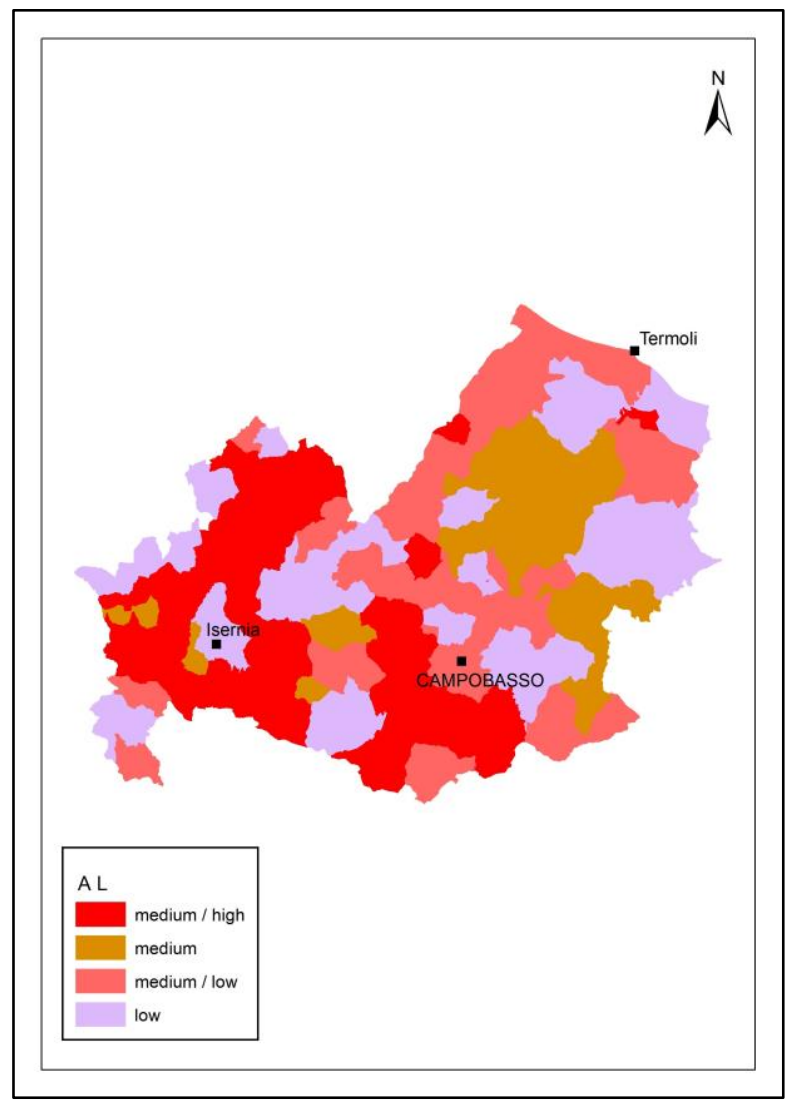

Fig 5. Zoning based on agricultural landscape indicators in the Molise Region. Source: own processing, 2016 
Regarding the levels of tourism development, tourism in Molise (fig. 6) is oriented on the whole, towards a traditional offer where the seaside resort areas and the ski stations (Campitello di San Massimo and Capracotta) are the most sought after, even if the centralised urban areas also provide attraction sites (Mastronardi \& De Gregorio 2012; Cialdea et al. 2015). More specifically, the major attraction points are situated in Termoli and along the coast that accommodate visitor flows from the surrounding regional areas, from northern Italy and to a small extent from abroad. In the remaining territory, the reception density is principally low because the main access highways and public transport favour the Termoli-Campobasso-Isernia-Venafro axis in comparison to secondary roadways and transport systems. The chronic lack of information regarding cultural and natural attractions in comparison to the rest of Italy also results in a lower number of visitors. There is one exception to visitor flows and this regards the Capracotta-Agnone. Vastogirardi hub which is characterised by various summer time tourism activities, (Mab ReserveUnesco of Montedimezzo), with winter time tourism activities (ski slopes and tracks), cultural activities (craftsmanship associated with the bell factory in Agnone and typical cuisine and gastronomy). Accommodation regarding the capital and principal urban centre in the region (Campobasso) is partially spread out in various "satellite" accommodation structures in respect to other city centres (Castropignano stands out among these).

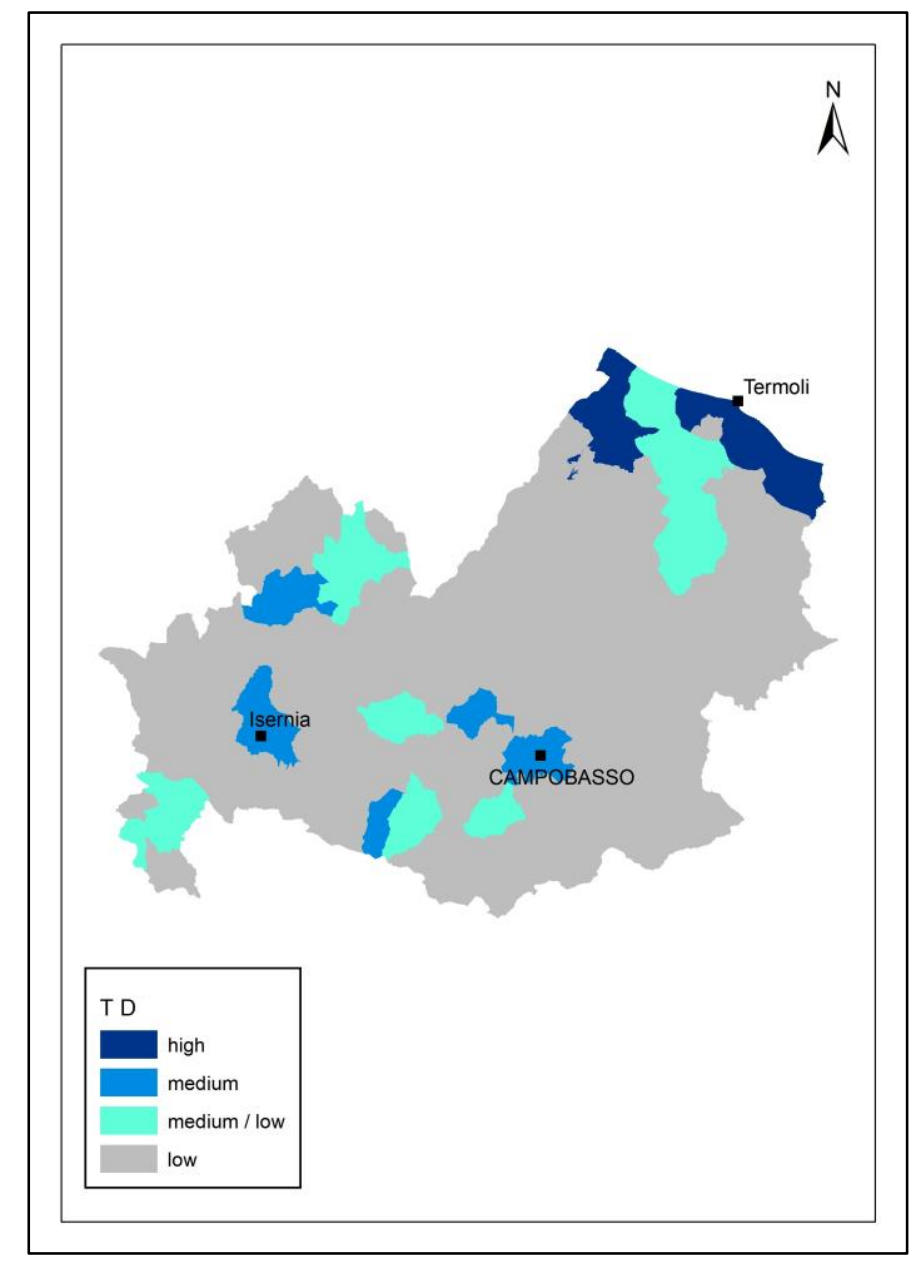

Fig 6. The level of tourism development in the region of Molise. Source: own processing, 2016

\subsection{Framework of the relations between tourism and landscape}

In applying the aforementioned research method, eight different association types regarding the level of tourism development (TD), natural landscape value (NLV) and agricultural landscape value $(A L)$ were derived. They have been registered using different codes and colours in figure 7 .

Type A11, found only in the municipality of Vastogirardi (IS), illustrates a tourism development model compatible with the high agricultural and naturalistic landscape values found in the Mab 
Reserve. The Reserve's main objective is to "maintain an equilibrium over time between Man and his Environment through the conservation of biological diversity, the promotion of economic development and the safeguarding of cultural values. ${ }^{11}$ It influences the ways and processes of territory transformation so that the growth of human activities and in particular, "eco-friendly" accommodation structures, namely, agricultural farmhouse, and bed and breakfast structures do not have an invasive effect on the landscape and in other words do not alter it over a period of time (other itineraries ASSOMAB).

While B121 and B112 types identify those areas where the majority of accommodation structures are associated with a satisfactory state of conservation in a sole component, the natural landscape, as in the case of the municipality of San Massimo, is hosting the region's principal ski station. Also identified is the countryside in the municipality of Castropignano, which is crossed by the "tratturi", connecting Lucera to Castel Di Sangro.

Type C22 identifies the most populous areas of the region where the natural and agricultural landscape do not represent the principal element of attraction. The presence of accommodation structures is correlated above all to the services present in the urban centres as in the case of each province's capital city (Campobasso and Isernia). It is also correlated to the seaside resort areas present along the entire coast, with the exception of the municipality of Petacciato where tourism flows are relatively lower. The coastal areas of the Molise region, however, still conserve bits of nature that have all but disappeared along the Adriatic coast (for example the dunes system with rare priority habitats, wetlands with a wide variety of winged/stationary or migratory bird species). These elements are so important that they justify the convergence of principal studies and resources in the environmental field of the region with the eco-sustainable restoration and enhancement of degraded natural and rural areas (Forleo et al. 2009; Di Marzio et al. 2009; Stanisci et al. 2014).

Type C11 identifies those areas characterized by high levels of natural and agricultural landscapes that have not been affected by adequate tourism development, in other words, the "gap" areas. These areas, with the proper promotional strategies and sustainable valorisation have the potential to become A11 type areas. These areas include, in particular, those municipalities where natural reserves are situated within the Molise territory of the Matese Mountain Chain (Guardiaregia-Campochiaro e Roccamandolfi), the upper valley of the Volturno River and the nearby Mainarde Mountain Chain (Molise region PNALM territory), along with the mountain of Capracotta, on the whole, safeguarded by State owned reserves and $\mathrm{SCl}$ areas.

The B212 type identifies gap areas with the main aim of promoting naturalistic tourism. This type is found in the upper valley of the Trigno River (with its main Mab hub in Collemeluccio and the archaeological site in Pietrabbondante). The municipality of San Pietro Avellana (with its forest centres of Mount Miglio and Mount Capraro) and the Zittola Quagmire, an important swampland on the PNALM borders are also included in this type. If improvements (such as the recovery of the sheep track-the tratturo) are made to this agricultural area, it could be turned into an inviting tourist attraction. In a specific sense, type B221 identifies the gap areas that have a prevalent vocation towards rural tourism as in the case of the Samnium Mountains and the lake basins of Guardialfiera and Occhito whose natural settings merit quality improvement.

The residual category (type A22), characterised by low natural and agricultural value levels, with a scarce presence of accommodation structures, is essentially an agricultural area. However, in some cases, it presents high levels of landscape and environmental potentiality as in the case of the municipality of Sepino. The town hosts the archaeological site Altilia (the region's most important) while also crossed by the Pescasseroli-Candela "tratturo" and the mountain oasis of Campitello.

\footnotetext{
11 http://www.riservamabaltomolise.it/la-riserva/il-programma-man-and-biosphere-unesco.html
} 


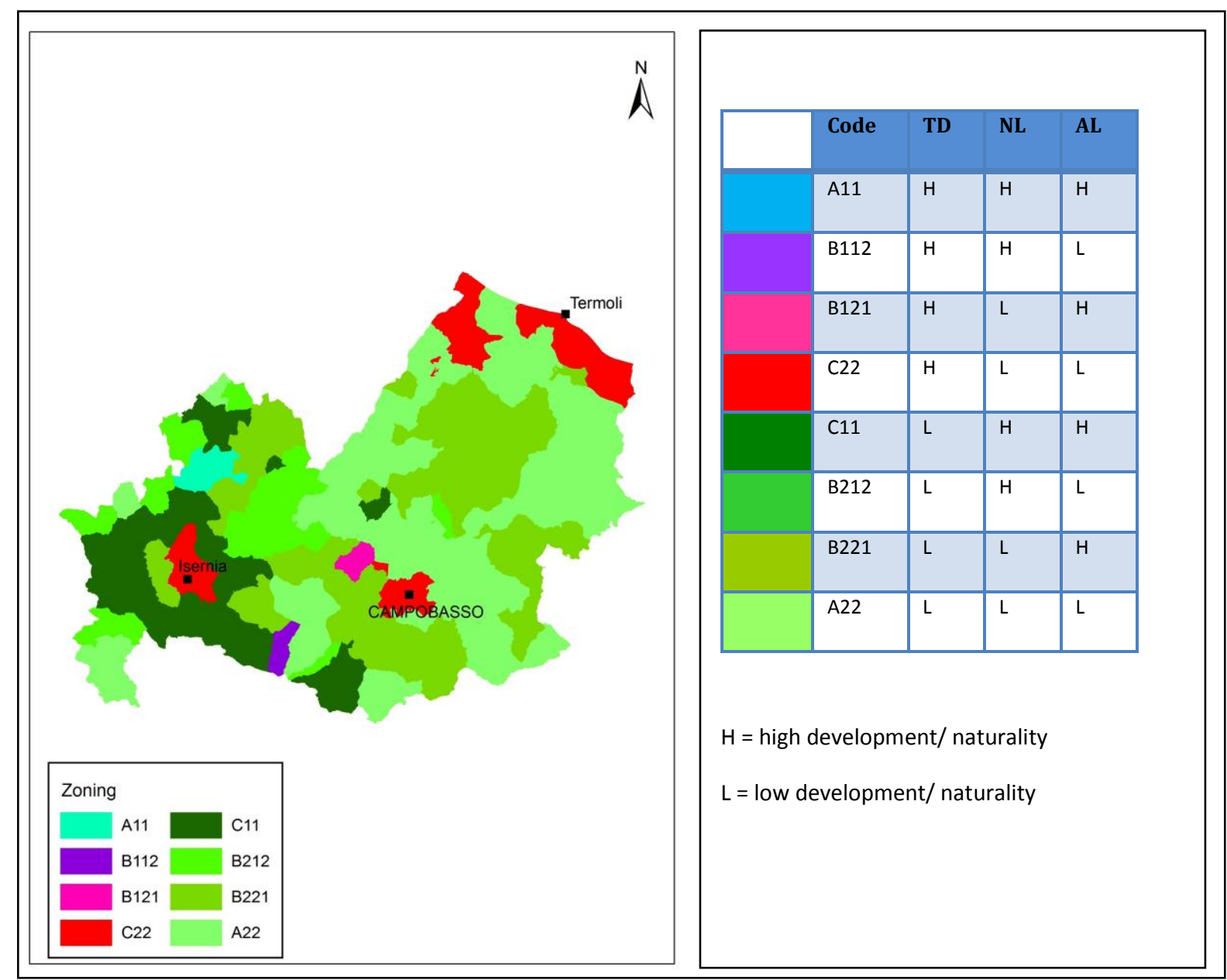

Fig 7. Synthesis of the relation between the level of tourism development and natural/agricultural landscape present in the region of Molise. Source: own processing, 2016

\section{Conclusion}

This paper has shed some light on several aspects regarding the role of natural and agricultural landscape in the tourism development process of rural areas.

The research method applied has allowed us to identify, from naturalistic and agricultural angles, those areas of value, in which to experiment policies. These are based on the recognition of the existing relationships between the landscape and tourism, in order to start up a process of sustainable tourism development.

In marginal areas, characterized by high quality landscape, tourism could have a great potential for growth, in the presence of other factors, i.e. infrastructures. Moreover, the analysis highlights the presence of several gap areas where natural and rural landscape has high quality level and slow tourism practices should be encouraged.

In those municipalities that possess high levels of natural and agricultural landscapes, the accommodation index, in fact, results in being substantially modest with few exceptions. On the other hand, in those municipalities whose territories result in lower values, the index of tourism development is higher. It is to be said, however, that the landscape considered for its esthetic and natural value finds no recognition in its role as an economic resource. Tourism enterprises, in fact, have not understood the potentiality that landscape possesses in attracting tourist flows, above all in hidden/marginal areas. For those companies operating in tourism cities with high tourist flows, landscape is seen as a complimentary aspect of the other economic enterprises, even apart from it, as for example those recreational activities connected to culture, the seaside or the mountains. Landscape is certainly a very important element in territorial competition, but on its own, it does not seem to be a key factor in stimulating tourism growth in rural areas. In 
relation to this statement, it is necessary to implement tourism-territorial policies, together with actions enhancing naturalistic and agricultural patrimony (i.e., Payment for Ecosystem Services - PEI, Nature 2000 Network and recovery of rural settlement) along with those connected to "socalled" rural amenities (Deller et al., 2001). In this manner, priority is given to those areas with major naturalistic and agricultural values while respecting ecological balance in the light of permanent local (tourism) development.

\section{Academic references}

[1] Antrop, M. (2005). Why landscapes of the past are important for the future. Landscape Urban Plan. 70(1-2): 21-34. Doi: 10.1016/j.landurbplan.2003.10.002.

[2] Basile, E. \& Cecchi, C. (2001). La Trasformazione Post-Industriale della Campagna. Torino: Rosenberg \& Sellier.

[3] Battaglini, E. \& Mastronardi, L. (2015). Turismo sostenibile e tensioni urbane nel terzo millennio - Città e Territorio Virtuale-Città Memoria Gente: 1538-1543. Roma: Università degli Studi Roma Tre.

[4] Beaufoy, G., Baldock, D. \& Clark, J. (1994). The Nature of Farming: Low Intensity Farming Systems in Nine European Countries. London: Institute for European Environmental Policy.

[5] Belletti, G. \& Berti, G. (2011). Turismo, ruralità e sostenibilità attraverso l'analisi delle configurazioni turistiche. In Pacciani A., ed., Aree rurali e configurazioni turistiche: differenziazione e sentieri di sviluppo in Toscana (pp. 21-62). Milano: Franco Angeli.

[6] Bignal, E. M. \& McCracken, D. I. (1996). Low-intensity farming systems in the conservation of the countryside. Journal of Applied Ecology 33, 413-424. Doi: 10.2307/2404804.

[7] Briedenhann, J. \& Wickens, E. (2004). Tourism routes as a tool for the economic development of rural areas - vibrant hope or impossible dream? Tourism Management 25(1), 71-79. Doi: 10.1016/S0261-5177(03)00063-3.

[8] Brunori, G. (2010). Lo sviluppo rurale tra processi di cambiamento e nuovi paradigmi, Agriregionieuropa, 6(20). Retrieved from: http://www.agriregionieuropa.univpm.it/it.

[9] Brunori, G. \& Pieroni, P. (2006). La (ri-)costruzione sociale del paesaggio nella campagna contemporanea: processi, problematiche, politiche per uno sviluppo rurale sostenibile. In Marangon, F., ed., Gli interventi paesaggistico-ambientali nelle politiche regionali di sviluppo rurale. Milano: Franco Angeli.

[10] Carranza, M. L., Barile, M., De Castro, G. De Lisio, L., Loy, A., Presti, G. \& Stanisci, A. (2006). Un modello di rete ecologica multispecifica: vegetazione e fauna dell'Alto Molise. Biogeographia: 207-220. Doi: 10.21426/B6110127.

[11] Carson, R. (1962). "Silent Spring”. Boston: Houghton Mifflin.

[12] Cavallo, A. \& Marino, D. (2014). Pianificazione paesaggistica, politiche agrarie, politiche ambientali e PAT: quali possibili indicazioni? In: Barbera, G., Biasi, R. \& Marino, D., eds., I paesaggi agrari tradizionali: un percorso per la conoscenza. Franco Angeli, Milano.

[13] Cawley, M. \& Gillmor, D. A. (2008). Integrated rural tourism: concepts and practice. Annals of Tourism Research 35(2): 316-337. Doi: 10.1016/j.annals.2007.07.011.

[14] Cialdea, D. \& Mastronardi, L. (2014a). Integrated approach in the planning stage for landscape conservation in the coastal Italian areas. International Journal of Design \& Nature and Ecodynamics 9(4), 296-306. Doi: 10.2495/DNE-V9-N4-296-306.

[15] Cialdea, D. \& Mastronardi, L. (2014b). Renewable energy resources and their impact on rural landscape. WSEAS Transactions on Environment and Development 10, 423-433.

[16] Cialdea, D. \& Mastronardi, L. (2014c). New land use in rural marginal areas. Renewable energy vs landscape preservation. In Mastorakis, N., Sokolov, V., Neck, R. et al, eds., 
Advances in Environmental Sciences, Development and Chemistry (pp. 468-474). New York: Springer US.

[17] Cialdea, D. \& Mastronardi, L. (2014d). A Multi-Criteria Methodology Oriented to the Preservation of the Coastal Areas Landscape. In: Batzias, F. et al., eds., Recent Advances in Energy, Environment and Financial Planning (pp. 237-246). WSEAS Press.

[18] Cialdea, D. \& Mastronardi, L. (2014e). Marginality Phenomena and New Uses on the Agricultural Land. Diachronic and Spatial Analyses of the Molise Coastal Area. TeMA, Special Issue, 235-245. Doi: 10.6092/1970-9870/2519.

[19] Cialdea, D., Mastronardi, L. \& Giannelli, A. (2015). Data-tourism Spatialization: a New Methodology Useful for Landscape Planning Assessment. In Nijkamp, P. et al., eds., Proceedings of the $5^{\text {th }}$ Central European Conference in Regional Science (114-124). Košice: Technical University.

[20] Cialdea, D. \& Mastronardi, L. (2015). La rete dei tratturi in Molise: implicazioni territoriali e strategie di gestione. Urbanistica Informazioni 263.

[21] Cialdea, D. \& Mastronardi, L. (2016). The Landscape Assessment for the New Energy Facilities. An integrated approach for Innovative Territorial Policies. In: Papa, R. \& Fistola, R., eds., Smart Energy in the Smart City. Urban Planning for a Sustainable Future (pp. 131150). Berlin: Springer.

[22] Cornes, R. \& Sandler, T. (1996). The Theory of Externalities, Public Goods and Club Goods, $2^{\text {nd }}$ Ed. Cambridge University Press.

[23] Croce, E. \& Perri, G. (2008). II turismo enogastronomico progettare, gestire, vivere l'integrazione tra cibo, viaggio, territorio. Milano: Franco Angeli.

[24] Daugstad, K., Rønningen, K. \& Skarb, B. (2006). Agriculture as an upholder of cultural heritage? Conceptualizations and value judgements - A Norwegian perspective in international context. Journal of Rural Studies, 22(1), 67-81. Doi: 10.1016/j.jrurstud.2005.06.002.

[25] Daugstad, K. (2008). Negotiating landscape in rural tourism, Annals of Tourism Research, 35(2), 402-426. Doi: 10.1016/j.annals.2007.10.001.

[26] Deller, S. C., Tsung-Hsiu, T., Marcouiller, D. W. \& English, D. B. K. (2001). The Role of Amenities and Quality of Life in Rural Economic Growth. American Journal of Agricultural Economics 83(2), 352-65.

[27] Dematteis, G. \& Governa, F. (2005). Territorialità, sviluppo locale, sostenibilità: il modello SLoT. Milano: FrancoAngeli.

[28] Di Marzio, P., Di Martino, P., Giancola, C. \& Mastronardi, L. (2008). II basso Molise. In Tassinari, P., ed., Le trasformazioni dei paesaggi nel territorio rurale: le ragioni del cambiamento e possibili scenari futuri. Approfondimenti interdisciplinari per la salvaguardia, la gestione e la pianificazione (pp. 39-42 + 188, 189, 190). Roma: Gangemi Editore.

[29] Di Marzio, P., Di Martino, P., Mastronardi, L., Fortini, P., Giancola, C. \& Viscosi, V. (2009): Analisi integrata socio-economica e di copertura del suolo in un paesaggio a prevalente matrice agricola. Italian Journal of Agronomy/Rivista di Agronomia 4(3), 47-52.

[30] Dwyer, J., Baldock, D., Beaufoy, G., Bennett, H., Lowe, P. \& Ward, N. (2003). Europe's Rural Futures - The Nature of Rural Development II Rural Development in an Enlarging European Union. London: WWF Europe and Institute for European Environmental Policy.

[31] Fleischer, A. \& Tchetchik, A. (2005). Does rural tourism benefit from agriculture? Tourism Management 26(4), 493-501. Doi: 10.1016/j.tourman.2003.10.003.

[32] Forleo, M. B. \& Mastronardi, L. (2008). Riflessioni per una strategia di sviluppo del turismo nelle aree rurali del Molise. In Bagarani, M., ed., Letture dello sviluppo rurale. Milano: Franco Angeli. 
[33] Forleo, M. B., Giaccio, V. \& Mastronardi, L. (2011). L'agricoltura nel sistema socioeconomico territoriali del Basso Molise. In Carrabba, P., Padovani, L. M., De Mei, M., Stanisci, A. \& Carranza, M. L., eds., II Progetto DINAMO per la biodiversità del Molise (pp. 40-64). Roma: ENEA.

[34] Franch, M. (2010). Marketing delle destinazioni turistiche. Metodi, approcci e strumenti. Milano: McGraw-Hill.

[35] Frochot, I. (2005). A benefit segmentation of tourists in rural areas: a Scottish perspective. Tourism Management 26(3), 335-346. Doi: 10.1016/j.tourman.2003.11.016.

[36] Garrod, B., Wornell, R. \& Youell, R. (2006). Re-conceptualising rural resources as countryside capital: the case of rural tourism. Journal of Rural Studies 22(1), 117-128. Doi: 10.1016/j.jrurstud.2005.08.001.

[37] Giaccio, V. \& Mastronardi, L. (2011). Le performance delle aziende agrarie con e senza agriturismo: un confronto con i dati RICA, Agriregionieuropa n. 26. Retrieved from: http://www.agriregionieuropa.univpm.it/it.

[38] Gregori, M. \& Piccinini, L. C. (2004). La valorizzazione del paesaggio nello sviluppo rurale, Agribusiness Paesaggio \& Ambiente 7(3), 189-213.

[39] Hotelling, H. (1933). Analysis of a complex of statistical variables into principal components. Journal of Educational Psychology, 24, 417-441. Doi: 10.1037/h0071325.

[40] Hotelling, H. (1936). Relations between two sets of variates. Biometrika 28(3/4): 321-77.

[41] Kneafsey, M. (2001). Rural cultural economy: tourism and social relations. Annals of Tourism Research, 28(3), 762-783. Doi: 10.1016/S0160-7383(00)00077-3.

[42] Marino, D. \& Cavallo, A. (2009). Rapporti coevolutivi tra costruzione sociale e caratteri naturali: il paesaggio agrario tradizionale. Rivista di Economia Agraria, vol. 3-4.

[43] Marsden, T. (1998). New rural territories: regulating the differentiated rural spaces. Journal of Rural Studies 14(1), 107-117. Doi: 10.1016/S0743-0167(97)00041-7.

[44] Mastronardi, L. \& Cipollina, M. (2009). Una riflessione sulla sostenibilità del turismo rurale alla luce dei legami tra agricoltura, turismo e ambiente, Rivista di Economia Agraria 1-2: 195-224.

[45] Mastronardi, L., Battaglini, E., Carranza, M. L., Giannelli, A., Stanisci, A. \& Truglia, F. G. (2012). Analisi delle relazioni tra il mosaico paesaggistico-naturalistico ed il turismo nelle aree rurali: prospettive metodologiche ed applicative. Annali del turismo, 1, no paging.

[46] Mastronardi, L. \& De Gregorio, D. (2012). II fenomeno della stagionalità e le conseguenze sull'ambiente. In: Meini, M. (ed.), Il turismo al plurale. Una lettura integrata del territorio per un'offerta turistica sostenibile. Franco Angeli, Milano.

[47] Mastronardi, L., Giaccio, V., Giannelli, A. \& Scardera, A. (2015a). Is agrituourism ecofriendly? Empirical evidence from Italy. SpringerPlus 4, 590. Doi:10.1186/s40064-015-13534.

[48] Mastronardi, L., Giaccio, V., Giannelli, A. \& Scardera, A. (2015b). Agriturismo e sostenibilità ambientale. Primi risultati di un'analisi aziendale, Agriregionieuropa 40, 55-58. Retrieved from: http://www.agriregionieuropa.univpm.it/it.

[49] Mastronardi, L., De Francesco, M. C., Giannelli, A. \& Stanisci, A. (2015c): Biodiversità e turismo nella costa teatina: conflitto o complementarietà? Geotema, 49, 126-131.

[50] Murdoch, J. \& Ward, N. (1997). Governmentality and territoriality: the statistical manufacture of Britain's «national farm». Political Geography 16(4): 307-324. Doi:10.1016/S09626298(96)00007-8.

[51] Murdoch, J., Lowe, P., Ward, N. \& Marsden, T. (2003). The differentiated countryside, London: Routledge. 
[52] Ohe, Y. \& Ciani, A. (2011). Evaluation of agritourism activity in Italy: facility based or local culture based? Tourism Economics 17(3): 581-601.

[53] Pistacchio, G. (2008). Verso una metodologia di zonizzazione del territorio regionale. In Bagarani, M., ed., Letture dello sviluppo rurale. Milano: Franco Angeli.

[54] Potočnik-Slavič, I. \& Schmitz, S. (2013). Farm tourism across Europe. European Countryside, 5(4), 265-274. Doi: 10.2478/euco-2013-0017.

[55] Printsmann, A., Kruse, A. \& Roth, M. (2012). Introduction for living in agricultural landscapes: practice, heritage and identity. European Countryside 4(2), 89-100. Doi: 10.2478/v10091012-0016-5.

[56] Ray, C. (1998). Culture, Intellectual Property and Territorial Rural Development. Sociologia Ruralis 38(1), 3-20. Doi: 10.1111/1467-9523.00060.

[57] Roberts, L. \& Hall, D. (2001). Rural Tourism and Recreation: Principles to Practice. Wallingford: CABI Publishing. Doi: 10.1079/9780851995403.0000.

[58] Saxena, G., Clark, G., Oliver, T. \& Ilbery, B. (2007). Conceptualizing integrated rural tourism. Tourism Geographies 9(4), 347-370. Doi: 10.1080/14616680701647527.

[59] Saxena, G. \& Ilbery, B. (2008). Integrated rural tourism, a border case study. Annals of Tourism Research. 35(1), 233-254. Doi: 10.1016/j.annals.2007.07.010.

[60] Sedlacek, S., Kurka, B. \& Maier, G. (2009). Regional identity: a key to overcome structural weaknesses in peripheral rural regions? European Countryside 1(4): 180-201. Doi: 10.2478/v10091-009-0015-3.

[61] Sereni, E. (1961). Storia del paesaggio agrario italiano. Bari: Laterza.

[62] Sharpley, R. (1996). Tourism \& Leisure in the Countryside $2^{\text {nd }}$ Ed. Huntingdon: ELM Publications.

[63] Stanisci, A., Acosta, A. T. R., Carranza, M. L., Feola, S. \& Giuliano, M. (2008). Gli habitat di interesse comunitario sul litorale molisano e il loro valore naturalistico su base floristica. Fitosociologia 44(2), Suppl. 1, 171-176.

[64] Stanisci, A., Acosta, A. T. R., Carranza, M. L., De Chiro, M., Del Vecchio, M. S., Di Martino, L., Frattaroli, A. R., Fusco, S., Izzi, C. F., Pirone, G. \& Prisco, I. (2014). EU habitats monitoring along the coastal dunes of the LTER sites of Abruzzo and Molise (Italy). Plant Sociology 51(1), 51-56. Doi 10.7338/pls2014512S1/07.

[65] Turri, E. (2008). Antropologia del paesaggio. Venezia: Marsilio.

[66] van der Ploeg, J. D. (2009). The new peasantries: struggle for autonomy and sustainability in an era of empire and globalization. London and Sterling (VA): Earthscan. Doi: 10.1007/s10745-010-9372-9.

\section{Other sources}

[67] European Commission (1988). The future of rural society, Com (88) 371 final. Brussels.

[68] European Environment Agency (2004). High nature value farmland: Characteristics, trends and policy challenges, EAA Report n.1, Copenhagen.

[69] Mastronardi, L. \& Fanelli, C. (2008). Antichi sentieri e sviluppo rurale. La rete dei tratturi e gli usi compatibili: quadro concettuale e verifica empirica. XII Convegno internazionale interdisciplinare IPSAPA/ISPALEM, Cividale del Friuli 25-26 Ottobre 2007. "Volontà, libertà e necessità nella creazione del mosaico paesistico-culturale". In Architettura del Paesaggio - CD Overview, allegato al n. 18.

[70] OECD (2006a). Rural Policy Reviews: The New Rural Paradigm: Policies and Governance. Paris: OECD publications. 
[71] OECD (2006b). Rural employment indicators. Paris: OECD publications.

[72] Paura, B. \& Stanisci, A. (2009). Le IPA in Molise. In: Blasi, C., Marignani, M., Copiz, R. \& Fipaldini, M., eds., Cartografia delle aree importanti per le piante. Roma: Ed. MATTM.

[73] Ray, C. (2003). Governance and the neo-endogenous approach to rural development. Economic and Social Research Council (ESRC) Seminar: "Rural Social Exclusion and Governance", London, UK.

[74] Regione Molise (2010). Piano di Sviluppo Rurale 2007-2013. Regione Molise. 